to produce an outstanding race of Longhorn cattle, of New Leicester sheep and 'black' horses. The economic conditions of the time, too, encouraged his efforts, as those of others, because there was a rising demand for the meat-producing animal.

Of necessity Bakewell was an empiricist, but he was of an original cast of mind, and Prof. M. McG. Cooper, who contributes to this book a modern evaluation of Bakewell's work, estimates that his ideas were well over a century in advance of his time. So far as can now be learned, the main principles of Bakewell's breeding system was a degree of in-breeding which some have thought excessive, combined with what is now known as the progeny test, something largely neglected in the intervening century and a half. The results were so remarkable that Bakewell earned an international reputation in his own lifetime, and was sought out by visitors from all over the world. He could not, of course, have explained what he did in terms of modern genetical science, but he used the observed results of careful experiments. No doubt intelligent farmers had been in the habit, when they could, of selecting their best animsls to breed from in the hope that like begat like, but Bakewell led the way towards modern breeding. His new water meadows added to his supply of 'natural' feeding stuffs. It is unfortunate, as Prof. Pawson says, that his records, if he ever kept any other than in his memory, have vanished, and that little is known of his early life. Nevertheless, this book forms a welcome addition to our knowledge of one of our greatest farming pioneers. The fact that it adds little to an exposition of his methods in a more explicit manner is no fault of the author; the necessary evidence does not, in fact, exist.

G. E. FusseuL

\section{PRINCIPLES OF ANALYSIS}

\section{Quantitative Inorganic Analysis}

By Prof. G. Charlot and Denise Bézier. Translated by Dr. R. C. Murray. Pp. $x+691$. (London: Methuen and Co., Ltd. ; New York: John Wiley and Sons, Inc., 1957.) $84 s$.

HE chief aim of this unusual book seems to be to stimulate an interest in fundamental principles rather than to provide detailed descriptions of reliable analytical methods. The authors state that their book is no replacement for specialized works.

In the first half of the book the theoretical aspects of chemical analysis are emphasized, particularly in relation to physico-chemical methods: the thirtythree chapters deal with a variety of subjects, including not only those usually found in works on chemical analysis but also, as examples, with statistical methods, determinations in solvents other than pure water, electrography, coulometry, and the use of radioactivity in analysis. Some practical details are included, though the treatment of some subjects, such as emission spectrophotometry, is very brief and the reader is left to use the many references provided.

Part 2 of the book deals with the determination of sixty-five of the chemical elements and contains much succinct information, though here again the practising analyst will often need to refer to the many original papers and specialized books listed.
The authors have attempted to provide comprehensive, though sometimes very brief and uncritical information and some blemishes are inevitable. As examples, one would hesitate to rely on ferrous ammonium sulphate for the standardization of dichromate, and one wonders why on p. 480 the gravimetric determination of manganese as pyrophosphate is omitted, while the poor method based on weighing as trimanganic tetroxide is mentionod. There is no mention on p. 546 of the gravimetric method for the determination of potassium based on weighing platinum after a chloroplatinate precipitation. One is surprised to read on p. 392 that the determination of bromide in the presence of chloride is difficult; no mention is made of the work of Haslam et al. (Analyst, 75, 343; 1950).

However, despite its defects, the book should encourage the student of analytical chemistry to strive for a better understanding of his work and to explore the possibilities of new methods.

\section{O. HaRveY}

\section{REASON AND CONTROVERSY}

\section{Methods and Criteria of Reasoning}

An Inquiry into the Structure of Controversy. By Rupert Crawshay-Williams. (International Library of Psychology, Philosophy, and Scientific Method.) Pp. viii +296. (London: Routledge and Kegan Paul, Ltd., 1957.) 32s. net.

A $S$ its somewhat pretentious title indicates, this $A$ book deals with the various ways in which disagreements and controversies arise, and in which they can be resolved. Much of the argument expounds and applies ideas that have dominated recent philosophy ; unfortunately it is conducted in a repetitious manner, and in a terminology that does not conform to the standards of precision which it, itself, desider. ates. Some good points are made on the way, particularly concerning that fashionable shibboleth 'ordinary language'. Mr. R. Crawshay-Williams explicitly confines himself to what he calls 'testable' statements; he is not concerned with those which lack a decisionprocedure for their truth or falsity, although he rightly says that these may be illuminating or interesting in some ways. This restriction of topic, quite legitimate in itself, involves a notion of testability which is too simpliste. It is baldly asserted, on p. 258, that the only kind of evidence that can be adduced for any belief is 'scientific' evidence; this view, which recalls the logical positivism of the 'twenties, now requires defence, and should not be taken for granted.

If the word 'science' is given such a wide meaning that it becomes vacuous, the principle is trivial; if used in its proper sense, the principle should be stated in a way that faces up to recent criticisms of the verification principle, contemporary developments in ethics, and, indeed, the existence of history as a form of knowledge. Crawshay-Williams's task is to show how, by redefinition and explication, we can render indeterminate, and hence controversial, statements into determinate and testable ones. $\mathrm{He}$ discusses examples of scientific controversy ("Are viruses molecules or organisms ?', 'Is aphasia a pure or complex disorder ' ') in an interesting way which illuminates the conceptual tangles at issue, but which does not clarify or reinforce the main thesis. This is that the meaning of all descriptive statements is 